\title{
Management of Childhood Empyema as a Complication of Community Acquired Pneumonia
}

\author{
NAGWA A. MOHAMED, M.D.; KHALED S. ZAGHLOUL, M.D. and GHADA A. MOHAMED, M.Sc. \\ The Department of Pediatrics, Faculty of Medicine, Assiut University, Egypt
}

\begin{abstract}
Background: Pneumonia is one of the most common reasons for hospitalization in childhood. Although most bacterial pneumonia will resolve with treatment of the underlying infection, some cases will be complicated by the development of an empyema.
\end{abstract}

Aim of Study: To assess the degree of agreement of the lines of diagnosis and treatment of patients with complicated pneumonia and empyema with the European guidelines for management of childhood empyema.

Patients and Methods: This study is a prospective analysis of 60 patients of empyema that were diagnosed and managed at Assuit University Children Hospital over 12 months from 1 st March 2016-28th February 2017.

Results: History of prolonged pneumonic illness ( $>15$ days) and pleuritic pain were checked in $100 \%$ and $86.7 \%$ respectively. History of the cardinal signs (cough, fever and respiratory distress) and investigations as CXR, WBC count, blood culture, CRP and ESR of community acquired pneumonia was taken in $100 \%, 100 \%, 100 \%, 75 \%, 41.7 \%$ and $41.7 \%$ respectively. ELISA test and procalcitonin were not done in any of our patients. History of the lines of management of community acquired pneumonia was taken in $60 \%$ of patients. Investigations of empyema as CXR, chest CT scan, analysis of pleural fluid, chest ultrasound, sputum culture were done in $100 \%, 100 \%, 75 \%, 21.7,8.3 \%$ successively. Eighty five $\%$ were treated correctly by antibiotics and $65 \%$ operated on by chest tube drainage and $1.6 \%$ was operated upon by open thoracotomy with decortications. Fibrinolytic therapy was not done in any of our patients.

Conclusion: Empyema is still a respiratory problem in pediatrics. Evaluation of the studied patients were done perfectly except for some history points and some laboratory investigations that showed some defects. Management was perfectly done except for fibrinolytic therapy.

Key Words: Chest tube drainage - Empyema thoracis Fibrinolytic agents - Open decortications Thoracocentesis - Video-assisted thoracoscopic surgery.

Correspondence to: Dr. Nagwa A. Mohamed, The Department of Pediatrics, Faculty of Medicine, Assiut University, Egypt

\section{Introduction}

EMPYEMA is the most frequent suppurative complication of bacterial pneumonia in childhood. As parapneumonic effusion progresses, fibrin and cellular detritus accumulate, the purulent fluid becomes septated, and a thick peel forms over the visceral and parietal pleura. Parapneumonic pleural effusion is thus classified into 3 stages of progression: Exudative (stage 1), fibrinopurulent (stage 2), and organizational (stage 3) [1]

An estimated $0.6 \%$ to $2 \%$ of pneumonia cases in children are complicated by empyema. Since the 1990s, there has been a considerable worldwide increase in the incidence of empyema, with rates reaching $28.3 \%$ to $53 \%$ of all patients hospitalized for pneumonia [2].

The therapeutic management of Pediatric Parapneumonic Effusions and Empyema (PPE/PE) and the impact of initial therapeutic interventions on clinical outcome are the subject of controversial discussions. A recent study from central Europe demonstrated a striking lack of consensus on the treatment of this disease [3]

Although it has been reported that more than half of the children with parapneumonic effusion or pleural empyema can be managed successfully with antibiotics alone [4], there is some evidence that early invasive draining procedures including video-assisted thoracoscopic surgery or intrapleural fibrinolytic therapy could reduce the length of hospital stay [5].

In some studies, chemical debridement with intrapleural fibrinolytic therapy has been shown to reduce length of hospital stay compared to pleural draining catheter alone [6]. Recent recommendations consider antibiotic therapy alone to be 
a reasonable first line treatment option for complication-free small pleural effusions, and pleural drainage alone or with additional fibrinolytic therapy for treatment of children with moderate to large parapneumonic effusion or pleural empyema [7]

\section{Aim of work:}

The aim of this study is to assess the degree of agreement of the lines of management of our patients suffering from complicated pneumonia and empyema with the European guidelines for treatment of childhood empyema [8].

\section{Patients and Methods}

Our study was done on 60 children (age from 1.2-15 years) with pleural effusion admitted to Assiut University Children Hospital over 12 months from ${ }^{1 \mathrm{st}}$ of March 2016 till 28 th of February 2017 (prospective audit study).

\section{Research design:}

Cases of pleural effusion and empyema were diagnosed and managedat Assiut University Children Hospital over one year. The lines of management were compared with the European guidelines [8] for treatment of childhood empyema and the results were recorded.

The patients with history of community acquired pneumonia were classified into mild, moderate and severe degree according to the: General condition, respiratory rate, presence or absence of cyanosis, $\mathrm{O}_{2}$ saturation, presence or absence of circulatory failure, artificial respiratory management [8].

\section{Approach to the research:}

\section{History:}

Personal history: Name, age, sex, residence.

Complaint and its duration:

Present history:

- Toxic appearance.

- Shortness of breath.

- Fever.

- Cough.

- Pleuritic chest pain.

- Malaise.

\section{Chest examination:}

- Decreased chest expansion.

- Dullness to percussion of the affected side.
- Decreased breath sounds and/or pleural rub.

- Egophony (patient voices the letter "e", but when listening (auscultation) it sounds like "a".

Investigations of community acquired pneumonia:

- $C X R$ :

- Perihilar changes.

- Lobar consolidation.

- Patchy pneumonia.

- Blood culture:

- No growth/Bacterial growth.

- White blood cells count:

- Leukocytosis/normal.

- $C R P$ :

- Positive/negative.

- ESR

- ${ }^{1 \text { st }}$ hour/2 nd hour.

Management of community acquired pneumonia:

- Age from $1.2 Y$ to $5 Y$ :

Mild disease: Amoxicillin 45-50mg/kg (max.1 gm) orally/12h for 7 days.

Cefdinir $7 \mathrm{mg} / \mathrm{kg}$ orally $12 \mathrm{~h}$ for 5 days.

Cefuroxime $15 \mathrm{mg} / \mathrm{kg}$ orally $12 \mathrm{~h}$ for 5 days.

Moderate disease (lobar or lobular effusion): Benzyl penicillin 30 (50.000)/kg IV 6 hourly for 5 days plus azithromycin $10 \mathrm{mg} / \mathrm{kg}$ orally daily for 5 days.

Benzyl penicillin $30(50.000) / \mathrm{kg}$ IV 6 hourly for 5 days plus roxithromycin $4 \mathrm{mg} / \mathrm{kg}$ orally 12 hourly for 7 days.

Severe disease (large pleural effusion, systemic toxicity and/or oxygen dependence): Cefotaxime $25 \mathrm{mg} / \mathrm{kg}$ IV 8 hourly for 7 days plus azithromycin $10 \mathrm{mg} / \mathrm{kg}$ orally daily for 5 days.

- Age from 5 years to 15 years:

Mild disease: Amoxicillin 45-50mg/kg orally 12 hourly for 7 days plus azithromycin $10 \mathrm{mg} / \mathrm{kg}$ orally daily for 5 days.

Amoxicillin $45-50 \mathrm{mg} / \mathrm{kg}$ orally 12 hourly for 7 days plus clarithromycin $7.5 \mathrm{mg} / \mathrm{kg}$ orally 12 hourly for 7 days. 
Serious disease: Amoxicillin 45-50mg/kg orally 12 hourly for 7 days plusazithromycin $10 \mathrm{mg} / \mathrm{kg}$ orally daily for 5 days.

Amoxicillin 45-50mg/kg orally 12 hourly for 7 days plus clarithromycin $7.5 \mathrm{mg} / \mathrm{kg}$ orally 12 hourly for 7 days.

\section{Investigations of pleural empyema:}

- CXR.

\section{Chest ultrasound scans:}

- Chest CT scans.

\section{Analysis of pleural fluid:}

- Sputum culture.

\section{Management of pleural empyema:}

\section{Antibiotics:}

- Cefuroxime/cefotaxime 50mg/kg IV 8 hourly.

- Clindamycin 10mg/kg IV 8 his added when MRSA is suspected.

- For patients with anaphylactic penicillin allergy and severely ill patients: Vancomycin:

- <12 year: 30mg/kg (max 1g) IV,12 hourly.

- >12 year: $25 \mathrm{mg} / \mathrm{kg}(\max 1 \mathrm{~g})$ IV 12 hourly plus cefotaxime/ceftriaxone.

- 50mg/kg (max $2 \mathrm{~g}) \mathrm{IV} 8 \mathrm{~h}$.

\section{Operative therapy:}

- Chest tube drainage.

- Thoracotomy with decortication.

- Immediate surgery using video-assisted thoracoscopic surgery (VATS).

- Chest tube drainage with fibrinolytic agent.

\section{Fibrinolytic therapy:}

- (Streptokinase or urokinase).

\section{Results}

Our study was done on 60 children (1.2 to 15 years) with empyema admitted to Assiut University Children Hospital over 12 months from ${ }^{1 \text { st }}$ of March 2016 till 28 th of February 2017 (prospective studies).

Table (1) shows that $100 \%$ and $83.3 \%$ of patients were examined for respiratory distress and toxic appearance respectively. Respiratory distress and toxicity were present in $70 \%$ and $83.3 \%$ respectively.
Table (2) shows that history of the cardinal signs of community acquired pneumonia were taken in all patients $(100 \%)$, the most presenting complaint were cough (100\%), fever (80\%) and respiratory distress $(70 \%)$.

Table (3) shows that all patients were checked for history of prolonged pneumonic illness (>15 days) which was present in $45 \%$ of patients and $86.7 \%$ of patients were checked for history of pleuritic pain and it was present in $7.7 \%$ of cases.

Table (4) show that chest X-ray, white blood cell count, blood culture, CRP and ESR were done in $100 \%, 100 \%, 75 \%, 41.7 \%$ and $41.7 \%$ respectively. ELISA test and procalcitonin were recommended, but were not done.

There were no patients recorded at age 2-4 months in our study.

Table (5) shows the history taken about the management of community acquired pneumonia in the studied patients age from 1.2 years to 5 years $(n o=36)$. Eighteen out of 36 patients $(50 \%)$ were considered mild disease according to history taken, nine of them $(50 \%)$ received amoxicillin either in inadequate dose [3 cases $(16.6 \%)$ ] or inadequate duration [6 cases $(10 \%)]$ and 5/18 (27.7\%) received cefuroxime either in inadequate dose [2 cases (11.\%)] or inadequate duration [3 cases (16.6\%)]. Ten cases $(27.7 \%)$ were considered moderate disease, seven of them (70\%) received Benzyl penicillin plus azithromycin either in inadequate dose [ 5 cases $(50 \%)$ ] or inadequate duration [ 2 cases (20\%)]. Eight cases (22.3\%) were considered severe disease, five of them $(62.5 \%)$ received cefotaxime plus azithromycin in inadequate dose [ 2 cases $(25 \%)$ ] or inadequate duration [3 cases $(37.5 \%)$ ].

Table (6) shows evaluation of investigations of pleural empyema that were done in the studied patients. Chest radiographs, chest CT scan, analysis of pleural fluid, chest ultrasound, sputum culture were done in $100 \%, 100 \%, 75 \%, 21.7,8.3 \%$ successively.

Table (7) shows the evaluation of lines of management of pleural empyema in the studied patients. Out of sixty patients, 51 cases $(85 \%)$ were treated correctly by antibiotics and 39 cases $(65 \%)$ operated on upon chest tube drainage and one case $(1.6 \%)$ was operated by open thoracotomy with decortications. 
Table (1): Number of cases with toxic appearance and respiratory distress.

\begin{tabular}{lcccc}
\hline & Checked & Not checked & Present & Absent \\
\hline $\begin{array}{l}\text { Respiratory distress: } \\
\text { No }\end{array}$ & $60 / 60$ & $0 / 60$ & $42 / 60$ & $18 / 60$ \\
$\quad \%$ & $100 \%$ & $0 \%$ & $70 \%$ & $30 \%$ \\
$\begin{array}{l}\text { Toxicity: } \\
\text { No }\end{array}$ & & & & \\
$\%$ & $50 / 60$ & No & $50 / 60$ & No \\
& $83.3 \%$ & $\%$ & $83.3 \%$ & $\%$ \\
\hline
\end{tabular}

Table (2): History of the cardinal signs of community acquired pneumonia.

\begin{tabular}{lccc}
\hline Patients history & Taken & Not taken & No. of cases \\
\hline $\begin{array}{l}\text { Fever: } \\
\quad \text { No. } \\
\%\end{array}$ & $60 / 60$ & $0 / 60$ & $48 / 60$ \\
Cough: & $100 \%$ & $0 \%$ & $80 \%$ \\
$\quad$ No. & & & \\
$\quad \%$ & $60 / 60$ & $0 / 60$ & $60 / 60$ \\
Respiratory distress: & $100 \%$ & $0 \%$ & $100 \%$ \\
$\quad \begin{array}{l}\text { No. } \\
\%\end{array}$ & $60 / 60$ & $0 / 60$ & \\
$\quad 100 \%$ & $0 \%$ & $42 / 60$ \\
\hline
\end{tabular}

Table (3): History checked for prolonged pneumonic illness and prescence of pleuritic chest pain.

\begin{tabular}{lccc}
\hline History & Checked & Not checked & Present \\
\hline - Prolonged & $60 / 60$ & $0 / 60$ & $27 / 60$ \\
pneumonic illness & $100 \%$ & $0 \%$ & $45 \%$ \\
- Presence of pleuritic & $52 / 60$ & $8 / 60$ & $4 / 52$ \\
pain & $86.7 \%$ & $13.3 \%$ & $7.7 \%$ \\
\hline
\end{tabular}

Table (4): Evaluation of investigations of community acquired pneumonia that were done in the studied patients.

\begin{tabular}{|c|c|c|c|c|}
\hline \multicolumn{5}{|c|}{ Investigation } \\
\hline \multicolumn{2}{|c|}{ CXR } & \multicolumn{3}{|c|}{ Findings } \\
\hline Done & Not done & $\begin{array}{c}\text { Patchy } \\
\text { pneumonia }\end{array}$ & $\begin{array}{c}\text { Lobar } \\
\text { consolidation }\end{array}$ & $\begin{array}{l}\text { Perihilar } \\
\text { changes }\end{array}$ \\
\hline $\begin{array}{l}60 / 60 \\
100 \%\end{array}$ & $\begin{array}{l}0 / 60 \\
0 \%\end{array}$ & $\begin{array}{l}22 / 60 \\
36.7 \%\end{array}$ & $\begin{array}{l}21 / 60 \\
35 \%\end{array}$ & $\begin{array}{l}17 / 60 \\
28.3 \%\end{array}$ \\
\hline \multicolumn{3}{|c|}{ White blood cells count } & \multicolumn{2}{|c|}{ Results } \\
\hline Done & Not & & Leukocytosis & Normal \\
\hline $\begin{array}{l}60 / 60 \\
100 \%\end{array}$ & & & $\begin{array}{l}40 / 60 \\
66.7 \%\end{array}$ & $\begin{array}{l}20 / 60 \\
33.3 \%\end{array}$ \\
\hline
\end{tabular}

\begin{tabular}{|c|c|c|c|}
\hline \multicolumn{2}{|c|}{ Blood culture } & \multicolumn{2}{|c|}{ Results } \\
\hline Done & Not done & Bacterial growth & No growth \\
\hline $\begin{array}{l}45 / 60 \\
75 \%\end{array}$ & $\begin{array}{l}15 / 60 \\
25 \%\end{array}$ & $\begin{array}{l}25 / 45 \\
55.6 \%\end{array}$ & $\begin{array}{l}20 / 45 \\
44.4 \%\end{array}$ \\
\hline \multicolumn{2}{|c|}{ CRP } & \multicolumn{2}{|c|}{ Results } \\
\hline Done & Not done & Positive & Negative \\
\hline $\begin{array}{l}25 / 60 \\
41.7 \%\end{array}$ & $\begin{array}{l}35 / 60 \\
58.3 \%\end{array}$ & $\begin{array}{l}18 / 25 \\
72 \%\end{array}$ & $\begin{array}{l}7 / 25 \\
28 \%\end{array}$ \\
\hline \multicolumn{2}{|c|}{ ESR } & \multirow{2}{*}{\multicolumn{2}{|c|}{ Results }} \\
\hline \multicolumn{2}{|c|}{1 st hour } & & \\
\hline Done & Not done & Abnormal & Normal \\
\hline $\begin{array}{l}25 / 60 \\
41.7 \%\end{array}$ & $\begin{array}{l}35 / 60 \\
58.3 \%\end{array}$ & $\begin{array}{l}18 / 25 \\
72 \%\end{array}$ & $\begin{array}{l}7 / 25 \\
28 \%\end{array}$ \\
\hline \multicolumn{2}{|c|}{ 2nd hour } & \multirow{2}{*}{ Abnormal } & \multirow{2}{*}{ Normal } \\
\hline Done & $\overline{\text { Not done }}$ & & \\
\hline $\begin{array}{l}25 / 60 \\
41.7 \%\end{array}$ & $\begin{array}{l}35 / 60 \\
58.3 \%\end{array}$ & $\begin{array}{l}18 / 25 \\
72 \%\end{array}$ & $\begin{array}{l}7 / 25 \\
28 \%\end{array}$ \\
\hline
\end{tabular}

Table (5): History taken about the management of community acquired pneumonia in the studied patients aged from 1.2 years to 5 years (no $=36$ cases).

\begin{tabular}{|c|c|c|c|c|c|}
\hline \multirow{4}{*}{$\begin{array}{l}\text { Severity of the disease } \\
\text { Mild disease }(n=18)\end{array}$} & \multicolumn{5}{|c|}{ Treatment } \\
\hline & \multicolumn{4}{|c|}{ Received $(n=14)$} & \multirow{3}{*}{$\begin{array}{c}\text { Not } \\
\text { received } \\
(n=4)\end{array}$} \\
\hline & \multirow{2}{*}{ Correct } & \multicolumn{3}{|c|}{ Incorrect } & \\
\hline & & Dose & Duration & Total & \\
\hline Amoxicillin $45-50 \mathrm{mg} / \mathrm{kg}(\max .1 \mathrm{gm})$ orally 12 hourly for 7 days & Zero & $3(16.6 \%)$ & $6(33.3 \%)$ & $9(50 \%)$ & $4(22.2 \%)$ \\
\hline Cefdinir $7 \mathrm{mg} / \mathrm{kg}$ orally 12 hourly for 5 days & Zero & Zero & Zero & Zero & Zero \\
\hline Cefuroxime $15 \mathrm{mg} / \mathrm{kg}$ orally 12 hourly for 5 days & Zero & $2(11.1 \%)$ & $3(16.6 \%)$ & $5(27.7 \%)$ & Zero \\
\hline \multirow{3}{*}{ Moderate disease (lobar orlobular effusion) $(n=10)$} & \multicolumn{4}{|c|}{ Received $(n=7)$} & \multirow{3}{*}{$\begin{array}{c}\text { Not } \\
\text { received } \\
(n=3)\end{array}$} \\
\hline & \multirow{2}{*}{ Correct } & \multicolumn{3}{|c|}{ Incorrect } & \\
\hline & & Dose & Duration & Total & \\
\hline $\begin{array}{l}\text { - Benzyl penicillin } 30(50.000) / \mathrm{kg} \text { IV } 6 \text { hourly for } 5 \text { days plus } \\
\text { azithromycin } 10 \mathrm{mg} / \mathrm{kg} \text { orally daily for } 5 \text { days }\end{array}$ & Zero & $5(50 \%)$ & $2(20 \%)$ & $7(70 \%)$ & $3(30 \%)$ \\
\hline $\begin{array}{l}\text { - Benzyl penicillin } 30(50.000) / \mathrm{kg} \text { IV } 6 \text { hourly for } 5 \text { days plus } \\
\text { roxithromycin } 4 \mathrm{mg} / \mathrm{kg} \text { orally } 12 \text { hourly for } 7 \text { days }\end{array}$ & Zero & Zero & Zero & Zero & Zero \\
\hline \multirow{3}{*}{$\begin{array}{l}\text { Severe disease (large pleural effusion, } \\
\text { systemic toxicity and/or oxygen dependence) }(n=8)\end{array}$} & \multicolumn{4}{|c|}{ Received ( $\mathrm{n}=5$ ) } & \multirow{3}{*}{$\begin{array}{l}\text { Not } \\
\text { received }\end{array}$} \\
\hline & \multirow{2}{*}{ Correct } & \multicolumn{3}{|c|}{ Incorrect } & \\
\hline & & Dose & Duration & Total & \\
\hline $\begin{array}{l}\text { - Cefotaxime } 25 \mathrm{mg} / \mathrm{kg} \mathrm{IV} 8 \text { hourly for } 7 \text { days plus azithromycin } \\
10 \mathrm{mg} / \mathrm{kg} \text { orally daily for } 5 \text { days }\end{array}$ & Zero & $2(25 \%)$ & $3(37.5 \%)$ & $5(62.5 \%)$ & $3(37.5 \%)$ \\
\hline
\end{tabular}


Table (6): Evaluation of investigations of pleural empyema done in the studied patients.

\begin{tabular}{|c|c|c|c|}
\hline \multicolumn{4}{|c|}{ Investigation } \\
\hline \multicolumn{2}{|c|}{ CXR } & \multicolumn{2}{|c|}{ Findings } \\
\hline Done & Not done & Rt effusion & Lt effusion \\
\hline $60 / 60$ & $0 / 60$ & $29 / 60$ & $31 / 60$ \\
\hline $100 \%$ & $0 \%$ & $48.3 \%$ & $51.7 \%$ \\
\hline \multicolumn{2}{|c|}{ Chest CT scan } & \multicolumn{2}{|c|}{ Findings } \\
\hline Done & Not done & Positive & Negative \\
\hline $60 / 60$ & $0 / 60$ & $60 / 60$ & Zero \\
\hline $100 \%$ & $0 \%$ & $100 \%$ & Zero \\
\hline \multicolumn{2}{|c|}{ Analysis of pleural fluid } & \multicolumn{2}{|c|}{ Results } \\
\hline Done & Not done & Positive & Negative \\
\hline $45 / 60$ & $15 / 60$ & $19 / 45$ & $26 / 45$ \\
\hline $75 \%$ & $25 \%$ & $42.2 \%$ & $57.8 \%$ \\
\hline \multicolumn{2}{|c|}{ Chest ultrasound } & \multicolumn{2}{|c|}{ Findings } \\
\hline Done & Not done & Positive & Negative \\
\hline $13 / 60$ & $\begin{array}{l}47 / 60 \\
783 \%\end{array}$ & $13 / 13$ & Zero \\
\hline \multirow{2}{*}{\multicolumn{2}{|c|}{ Sputum culture }} & \multirow{2}{*}{\multicolumn{2}{|c|}{ Results }} \\
\hline & & & \\
\hline Done & Not done & Positive & Negative \\
\hline $\begin{array}{l}5 / 60 \\
8.3 \%\end{array}$ & $\begin{array}{l}55 / 60 \\
91.7 \%\end{array}$ & $\begin{array}{l}3 / 5 \\
60 \%\end{array}$ & $\begin{array}{l}2 / 5 \\
40 \%\end{array}$ \\
\hline & $91.7 \%$ & $60 \%$ & $40 \%$ \\
\hline
\end{tabular}

Table (7): Evaluation of lines of management of pleural empyema in the studied patients $(n=60)$.

\begin{tabular}{|c|c|c|c|}
\hline \multirow{2}{*}{ Antibiotics treatment } & \multicolumn{2}{|c|}{ Received } & \multirow{2}{*}{$\begin{array}{l}\text { Not } \\
\text { received }\end{array}$} \\
\hline & Correct & Incorrect & \\
\hline \multirow[t]{2}{*}{$\begin{array}{l}\text { - For patients with anaphylactic } \\
\text { penicillin allergy and severely ill } \\
\text { patients: Vancomycin } \\
\text { <12 year: } 30 \mathrm{mg} / \mathrm{kg} \text { (max } 1 \mathrm{~g}) \mathrm{IV}, 12 \\
\text { hourly. } \\
\text { >12 year: } 25 \mathrm{mg} / \mathrm{kg}(\max 1 \mathrm{~g}) \mathrm{IV}, 12 \\
\text { hourly plus cefotaxime/ceftriaxone } \\
50 \mathrm{mg} / \mathrm{kg}(\max 2 \mathrm{~g}) \mathrm{IV}, 8 \mathrm{~h}\end{array}$} & $\begin{array}{l}51 / 60 \\
85 \%\end{array}$ & $\begin{array}{l}\text { Zero } \\
\text { Zero }\end{array}$ & $\begin{array}{l}60 / 60 \\
100 \% \\
60 / 60 \\
100 \% \\
9 / 60 \\
15 \%\end{array}$ \\
\hline & \multicolumn{2}{|c|}{ Done } & Not done \\
\hline Operative therapy: & \multicolumn{2}{|c|}{$39 / 60$} & $21 / 60$ \\
\hline - Chest tube drainage & \multicolumn{2}{|c|}{$65 \%$} & $\begin{array}{l}35 \% \\
59 / 60\end{array}$ \\
\hline - Thoracotomy with decortication & \multicolumn{2}{|c|}{$1.6 \%$} & $\begin{array}{l}98.4 \% \\
60 / 60\end{array}$ \\
\hline - Immediate surgery using video- & \multicolumn{2}{|c|}{$0 \%$} & $\begin{array}{l}100 \% \\
60 / 60\end{array}$ \\
\hline $\begin{array}{l}\text { - Chest tube drainage with fibrinolytic } \\
\text { agent }\end{array}$ & \multicolumn{2}{|c|}{$0 \%$} & $100 \%$ \\
\hline $\begin{array}{l}\text { Fibrinolytic therapy: } \\
\text { (Streptokinase or urokinase) }\end{array}$ & \multicolumn{2}{|c|}{ Zero } & $\begin{array}{l}60 / 60 \\
100 \%\end{array}$ \\
\hline
\end{tabular}

\section{Discussion}

Our study revealed that all the patients whom suspected to have pleural effusion were admitted, diagnosed and treated in Assuit University Children Hospital. This is in agreement with Buckingham et al., and Schultz et al., who reported that empyema is one of the most common reasons for hospitalization in childhood $[9,10]$. In this study we noticed that the most common presenting complaint that enforce the patients to seek medical advice and accept hospital admission was cough in $100 \%$ of cases associated with fever in $80 \%$ and/or respiratory distress in $70 \%$ of them. Similarly Ferrer et al., mentioned that most patients with empyema presented with clinical manifestations of bacterial pneumonia, acute febrile response, pleuritic chest pain, cough, dyspnea, and, possibly, cyanosis [11].

In the present study some points were missed during history taking such as history of pleuritic chest pain and the relatives may give some inaccurate history due to defects in diagnosing previous period of illness.

The following investigations were done in all patients $(100 \%)$, white blood cell count (leukocytosis in $66.6 \%$ ), chest X-ray that showed patchy pneumonic changes, lobar consolidation, perihilar changes, right pleural effusion and left pleural effusion in $36.66 \%, 35 \%, 28.3 \%, 48.3 \%, 51.6 \%$ respectively. Chest CT scans were also done in $100 \%$ of patients to identify the underlying consolidated lung or fibrinous septations [12].

On the other hand some missed investigations were detected as:

1-Blood culture: That was done in $75 \%$ of cases, either because it was not recommended or the patients already started antibiotics at the emergency department. In pediatric patients, in whom sputum production is uncommon, identifying the cause of the pulmonary symptoms early in the course of a pulmonary infection is difficult. However, with parapneumonic effusions, the patient may become bacteremic as the organism invades into the pleural space, and a blood culture may reveal the organism [13] .

2- Analysis of pleural fluid: Was done in $75 \%$ of patients due to missed sample in emergency department. Analysis of the pleural fluid $\mathrm{pH}$, $\mathrm{LDH}$, and glucose levels in parapneumonic effusions is potentially useful in diagnosing empyema and guiding decisions on the need for drainage [14] 
3- ESR and CRP: Were done only in $41.6 \%$ of patients due to either it was not recommended or it was missed in Emergency Department.

4- Chest ultrasound was done in $21.6 \%$ of patients, and it is useful in diagnosing the underlying chest etiology of undifferentiated dyspnea and can identify loculated fluid collections [15].

5- Sputum culture: Was done in $8.3 \%$ of patients because it is difficult to be obtained in children at that age.

6- ELISA, Procalcitonin, Pleural fluid Polymerase Chain Reaction (PCR), latex agglutination tests were deficient, due to non recommendation or unavailability in our hospital. These tests could be helpful if the cause of the infection cannot be ascertained from stain or culture [16]

Out of sixty patients, 44 (73.3\%) of them had a history of receiving improper antibiotics either with inadequate dose or inadequate duration. $\mathrm{Pa}$ tients may present with complicated pneumonia or an initially uncomplicated pneumonia that is poorly responsive to antibiotics (persistent fever after $48 \mathrm{~h}$ to $72 \mathrm{~h}$ of antibiotics without clinical improvement, persistent or worsening respiratory distress and/or hypoxia, or new clinical findings of a pleural effusion) [17].

However $85 \%$ of our cases received the recommended antibiotics treatment of empyema with no evidence of using fibrinolytic therapy numerous studies have documented the effectiveness of intrapleural fibrinolytics to treat obstructed thoracostomy tubes, increase drainage in multiloculated effusions, and to lyse adhesions [18]. On the other hand $65 \%$ were subjected to empyema drainage with intercostal tube. Kirsch et al., reported patients who fail to respond to intravenous antibiotics and improving pulmonary symptoms, are those in whom pleural fluid does not aspirate with needle or tube thoracostomy, or present with Empyema Severity Scores (ESS) of 2 or greater that responded more quickly with earlier decortication [19]. Finally in our study only one case was advised for surgical treatment in the form of open thoracotomy with decortication.

\section{Conclusion:}

Empyema is still a problematic chest diseases in pediatrics. Evaluation of the studied patients were done perfectly except for some history points and laboratory investigations that showed some defects. Management was perfectly done except for fibrinolytic therapy.

\section{References}

1- MARHUENDA C., BARCELO C., FUENTES I., et al.: Urokinase versus VATS for treatment of empyema: A randomized multicenter clinical trial, Pediatrics, 134: e1301-e1307, 2014.

2- GRIJALVA C.G., NUORTI J.P., ZHU Y. and GRIFFIN M.R.: Increasing incidence of empyema complicating childhood community-acquired pneumonia in the United States. Clin. Infect. Dis., 50 (6): 805-13, 2010.

3- HAFEN G.M., GRENZBACH A.C., MOELLER A. and ROCHAT M.K.: Lack of concordance in parapneumonic effusion management in children in central Europe. Pediatr. Pulmonol., 51: 411-7, 2016.

4- CARTER E., WALDHAUSEN J., ZHANG W., HOFFMAN L. and REDDING G.: Management of children with empyema: Pleural drainage is not always necessary. Pediatr. Pulmonol., 45: 475-80, 2010.

5- PADMAN R., KING K.A., IQBAL S. and WOLFSON P.J.: Parapneumonic effusion and empyema in children: retrospective review of the duPont experience. Clin. Pediatr. (Phila), 46: 518-22, 2007.

6- ISLAM S., CALKINS C.M., GOLDIN A.B., CHEN C., DOWNARD C.D., HUANG E.Y., CASSIDY L., SAITO J., BLAKELY M.L., RANGEL S.J., et al.: The diagnosis and management of empyema in children: A comprehensive review from the APSA Outcomes and Clinical Trials Committee. J. Pediatr. Surg., 47: 2101-10, 2012.

7- BRADLEY J.S., BYINGTON C.L., SHAH S.S., ALVERSON B., CARTER E.R., HARRISON C., KAPLAN S.L., MACE S.E., McCRACKEN G.H., Jr., MOORE M.R., et al.: Pediatric Infectious Diseases Society and the Infectious Diseases Society of America. The management of communityacquired pneumonia in infants and children older than 3 months of age: Clinical practice guidelines by the Pediatric Infectious Diseases Society and the Infectious Diseases Society of America. Clin. Infect. Dis., 53: e25e76, 2011.

8- PROESMANS M. and DeBOECKK: Clinical practice: Treatment of childhood empyema. European Journal of Pediatrics, 168 (6): 639-45, 2009.

9- BUCKINGHAM S.C., KING M.D. and MILLER M.L.: Incidence and etiologies of complicated parapneumonic effusions in children, 1996 to 2001. Pediatr. Infect. Dis. J., 22: 499-504, 2003.

10- SCHULTZ K.D., FAN L.L., PINSKY J., et al.: The changing face of pleural empyemas in children: Epidemiology and management. Pediatrics, 113: 1735-40, 2004.

11- FERRER A., OSSET J., ALEGRE J., SURIÑACH J.M., CRESPO E., FERNÁNDEZ, De SEVILLA T. and FERNÁNDEZ F.: "Prospective clinical and microbiological study of pleural effusions". European Journal of Clinical Microbiology and Infectious Diseases, 18 (4): 237-41, 1999.

12- WONG C.L., HOLROYD-LEDUC J. and STRAUS S.E.: Imaging of pleural effusion. J.A.M.A., Jan 21, 301 (3): 309-17, 2009. 
13- NOPPEN M.: Normal volume and cellular contents of pleural fluid. Curr. Opin. Pulm. Med., Jul., 7 (4): 180-2, 2001.

14- FERNANDEZ-COTARELO M.J., LOPEZ-MEDRANO F., SAN JUAN R., AZ-PEDROCHE C., LIZASOAIN M., CHAVES F., AGUADO J.M., SAN JUAN R. and DIAZPEDROCHE C.: "Protean manifestations of pleural empyema caused by Streptococcus pneumoniae in pediatrics". European Journal of Internal Medicine, 18: 141-5, 2007.

15- STIGT J.A. and GROEN H.J.: Percutaneous ultrasonography as imaging modality and sampling guide for pulmonologists. Respiration, 87 (6): 441-51, 2014.

16- DOSKI J.J., LOU D. and HICKS B.A.: Investigations of parapneumonic collections in infants and children. J. Pediatr. Surg., 35: 265-70, 2000.

17- FINLEY C., CLIFTON J., FITZGERALD J.M. and YEE J.: Empyema: An increasing concern in Canada. Can. Respir. J., 15: 85-92, 2008.

18- SARIHAN H., CAY A., AYNACI M., TIRYAKI T., ABBASOGLU L., AKYAZICI R. and BAKI A.: Empyema in children. Cardiovasc. Surg. (Torino), 39: 113, 1998.

19- KIRSCH T.D., ROBERTS J.R. and HEDGES J.R.: Clinical Procedures in Emergency Medicine. 5 th ed. Saunders Elsevier, Respiratory Emergency, edition, p. 175-96, 2009.

\section{التدقيق على تشخيص وعلاج الإلتهاب الصلديلى البللورى الهئ

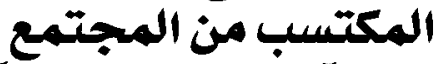 بمستشفى الآطفال الجامعى بآسيوط المئم}

إن الإلتهاب الرئقى يعد واحدا من الآسباب الرئيسية اللعلاج فى المستشفيات وخاصة فى فترة الطفولة.

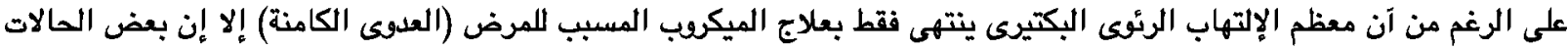

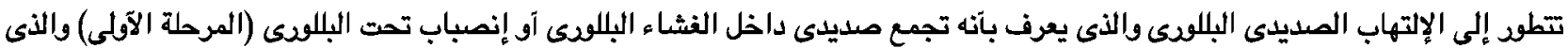

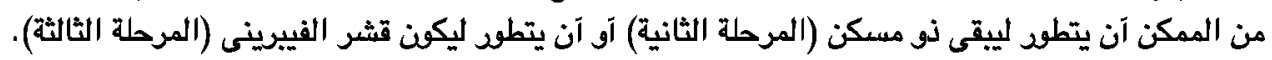
وهناك مضاعفات آخرى للإلتهاب الرئيى مثل خراج بالرئة والرئة النخرية. معظم الدراسات الحديثة تسجل إرتفاعا ملحوظا فى عدد الحالات التى تتطور من الإلتهاب الرئوى إلى الإلتهاب الصديدى البللوىى. تم تصميم البحث على الآطفال الذين تم دخولهم إلى مستشفى الآطفال الجامعى بآسيوط فى خلال سنة من بداية مارس 17 . Y وحتى نهاية

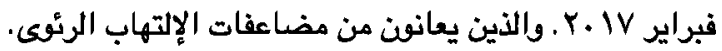

هو دراسة درجة التوافق بين خطة العلاج للمرضى الذين يعانهن من الإلتهاب الصديدى البللوىى الناتج عن الإلتهاب الرئوى مع القواعد

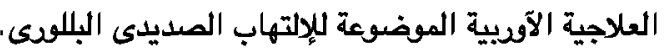

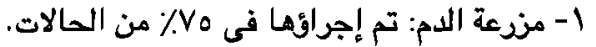

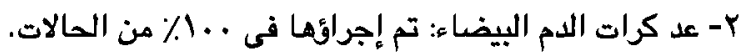

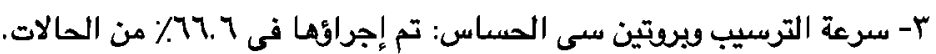

$$
\text { ع- اليزا وبروكالسيتونين: لم يتم إجراؤها. }
$$

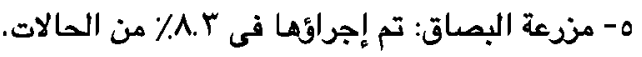

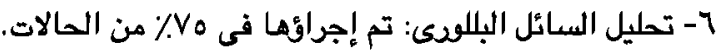$$
\text { ا- آثعة عادية على الصدر: تم إجراؤها فى . .1\% من الحالات. }
$$

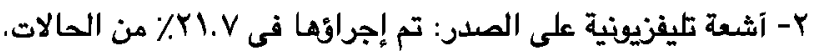

$$
\text { ا- آشعة مقطعية على الصدر: تم إجراؤها فى . . 1٪ من الحالات. }
$$

• إن الإلتهاب الصديدى البللودى يعد من المثاكل الصعبة فى الآطفال. • تقييم كل المرضى جاء كاملا ما عدا فى بعض النقاط في التاريخ المرضى والفحوصات والعلاج. 